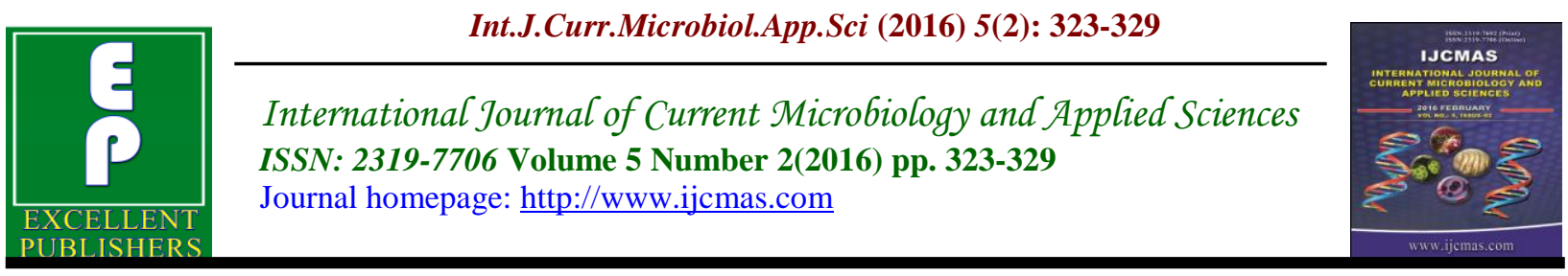

Original Research Article

doi: http://dx.doi.org/10.20546/ijcmas.2016.502.037

\title{
Urinary Pathogens and their Antibiotic Susceptibility Pattern in MIMS, Mandya, India
}

\author{
Mamatha P Samaga* and N.S. Sahana Shetty \\ Department of Microbiology, MIMS, Mandya, India \\ *Corresponding author
}

Keywords

Urinary tract infection, Gram-negative bacteria, Escherichia coli, Staphylococcus aureus

\section{Article Info}

Accepted:

17 January 2016 Available Online: 10, February 2016

\section{A B S T R A C T}

Urinary tract infection (UTI) represents one of the most common diseases encountered in medical practice today, occurring from the neonate to the geriatric age group. Urinary tract infection (UTI) can be caused by Gram-negative bacteria such as Escherichia coli, Klebsiella species, Enterobacter species, Proteus species and gram-positive bacteria like Enterococcus species, and Staphylococcus saprophyticus. This study was conducted to know the uropathogens and trend of antibiotic susceptibility pattern of uropathogens in our setting, thus can help in deciding empirical treatment of UTI. This retrospective study was carried out in the Department of Microbiology, MIMS, Mandya. The urinary pathogens and their antibiotics susceptibility patterns from January - December 2014( One year) were studied from the records of Microbiology laboratory. A total of 357 urine samples were processed. Among them, 127 (35.5\%) samples yielded significant growth. Among 110 samples from males, 30 ( $27.2 \%$ ) yielded significant growth, majority yielded Escherichia coli 18(60\%) followed by Staphylococcus aureus 3(10\%), Candida 3(10\%), Pseudomonas aeruginosa 2(6.7\%), Citrobacter 2(6.7\%) and Klebsiella 2(6.7\%). Among 247 samples from females, 97 (39.2\%) yielded significant growth, majority yielded Escherichia coli 34 (35\%) followed by Staphylococcus aureus 16 (16.4\%), CONS 11(11.3\%), Klebsiella 10(10.3\%), Candida 9(9.3\%), Enterococci 8 (8.2\%), Acinetobacter 5(5.1\%), Citrobacter $3(3 \%)$, and Morganella 1(1\%). Prevalence of UTIs was more in females(39.2\%) when compared to males(27.2\%). In our study E.coli was most resistant to Ampicillin (96.2\%). It was most sensitive to Imipenem (100\%) followed by Piperaciliin-tazobactum $(81.92 \%)$. All the Gram positive bacteria were also highly resistant to ampicillin and showed $100 \%$ sensitivity to vancomycin. Urinary pathogens showed resistance to commonly used antibiotics like Ampicillin, Cotrimoxazole. The susceptibility patterns of urinary pathogens should be considered before starting empirical treatment for UTI.

\section{Introduction}

Urinary tract infection (UTI) represents one of the most common diseases encountered in medical practice today, occurring from the neonate to the geriatric age group
(Tambekar, et al., 2006). A global estimation of yearly episodes of UTI could be in the range of 150 million with a large proportion of the infections being inapparent 
while some episodes manifest with obvious clinical features. (Al-Asmary SM et al., 2004) Manifestations of UTIs vary from mild symptomatic cystitis to pyelonephritis and septicemia (Naveen R et al., 2005).

Urinary tract infection (UTI) can be caused by Gram-negative bacteria such as Escherichia coli, Klebsiella species, Enterobacter species, Proteus species and gram-positive bacteria like Enterococcus species, and Staphylococcus saprophyticus. E. coli is the most common organism causing both community as well as hospital acquired UTI (Sobel JD et al., 2010).

Treatment of UTI is often started empirically and therapy is based on information determined from the antimicrobial resistance pattern of the urinary pathogens (Wilson ML, 2004). Distribution of urinary pathogens and their susceptibility to antibiotics varies regionally so it becomes necessary to have knowledge of distribution of these pathogens and their susceptibility to antibiotics in a particular setting (Farrell DJ et al., 2003).

Periodic evaluation of antimicrobial activity of different antibiotics is essential as the pattern of antibiotic sensitivity may vary over short periods (GK Rai et al., 2008).

This study was conducted to know the uropathogens and the antibiotic susceptibility pattern of uropathogens in our setting, thus can help in deciding empirical treatment of UTI.

\section{Materials and Methods}

This retrospective study was carried out in the Dept. of Microbiology, MIMS,Mandya. Approval was obtained from the Institutional Ethical Committee. The urinary pathogens and their antibiotics susceptibility patterns from January December 2014 (One year) were studied from the records of Microbiology laboratory. Clean catch midstream urine sample collected in sterile container was received in the Microbiology laboratory.

Microscopy was done and each sample processed on blood agar and mac conkey agar. Culture positive result was given if the number of bacteria grown on culture media exceeded $10^{5}$ colony forming units (CFU) per $\mathrm{ml}$ of urine in case of clean-catch midstream urine but based on type of urine sample (straight catheterisation) submitted and clinical history (acute urethral syndrome, antibiotic therapy) of the patient, lower colony counts $\left(10^{3} \mathrm{CFU} / \mathrm{ml}\right)$ were also considered significant in some cases. When polymorphic bacterial growth ( more than two bacterial species growth) was observed, the samples were classified as contaminated and excluded from the study. Bacterial identifi cation was done by colony morphology, Gram staining and standard biochemical tests (Betty AF et al., 2007).

Antibiotic susceptibility testing was done by Kirby Bauer disk diffusion method as per CLSI guidelines ( CLSI, 2011). Descriptive statistics was used to analyze the data. Antimicrobial sensitivity of the confirmed micro-organisms was done by disc diffusion method on Muler Hinton agar. Antibiotic susceptibility tests and interpretations were carried out for bacterial isolates by the Kirby-Bauer technique.( Bauer AW et al., 1966) The antibiotics tested were Nitrofurantoin(300 $\mu \mathrm{g})$, Amikacin(30 $\mu \mathrm{g})$, Cotrimoxazole $(25 \mu \mathrm{g})$, Gentamycin $(10 \mu \mathrm{g})$, Ciprofloxacin $(5 \mu \mathrm{g})$, Erythromycin(15 $\mu \mathrm{g})$, Nalidixic acid(30 $\mu \mathrm{g})$, Norfloxacin $(10 \mu \mathrm{g})$,

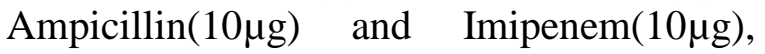
Cefotaxime $(30 \mu \mathrm{g}), \quad$ Ceftriaxone $(30 \mu \mathrm{g})$, oxacillin $(1 \mu \mathrm{g})$. 


\section{Results and Discussion}

A total of 357 urine samples were processed. 110 samples were from males and 247 were from females. Among them, 127 (35.5\%)samples yielded significant growth. Among 110 samples from males, 30 (27.2\%) yielded significant growth, $62 \quad(56.3 \%)$ showed no growth and 18 (16.3\%) had nonsignificant bacteriuria.

Among 30 samples from males with significant bacteriuria, majority yielded Escherichia coli, 18(60\%) followed by Staphylococcus aureus 3(10\%), Candida $3(10 \%)$, Pseudomonas aeruginosa 2(6.7\%), Citrobacter 2(6.7\%) and Klebsiella 2(6.7\%) (Fig 1).
Among 247 samples from females, 97 $(39.2 \%)$ yielded significant growth, 124 $(50.2 \%)$ yielded no growth and $25(10.1 \%)$ yielded non-significant bacteriuria. Among 97 samples with significant bacteriuria, majority yielded Escherichia coli 34 (35\%).Other isolates were Staphylococcus aureus 16 (16.4\%), CONS 11(11.3\%), Klebsiella 10(10.3\%), Candida 9(9.3\%), Enterococci 8 (8.2\%), Acinetobacter $5(5.1 \%), \quad$ Citrobacter 3(3\%), and Morganella 1(1\%) as shown in Fig 2. Prevalence of UTI was more in females compared to males.( Table 1).The antibiotic sensitivity pattern of Gram negative and Gram positive bacteria are shown in Tables 2 and 3 respectively.

Table.1 Sex-wise Distribution of Prevalence of Urinary Tract Infection

\begin{tabular}{|l|l|l|l|}
\hline SEX & No. of samples processed & $\begin{array}{l}\text { No. of samples with } \\
\text { significant growth }\end{array}$ & Percentage \\
\hline Male & 110 & 30 & 27.2 \\
\hline Female & 247 & 97 & 39.2 \\
\hline
\end{tabular}

Table.2 In vitro Antibiotic Sensitivity Pattern of Gram Negative Bacteria.Percentage is Written in Paranthesis

\begin{tabular}{|l|c|c|c|c|c|c|}
\hline & $\begin{array}{l}\text { E.coli } \\
\mathbf{N = 5 2}\end{array}$ & $\begin{array}{l}\text { Klebsiella } \\
\mathbf{N = 1 2}\end{array}$ & $\begin{array}{l}\text { Citrobacter } \\
\text { spp. } \boldsymbol{N = 5}\end{array}$ & $\begin{array}{l}\text { Pseudomonas } \\
\text { aeruginosa } \mathbf{N = 2}\end{array}$ & $\begin{array}{l}\text { Acinetobacter } \\
\mathbf{N = 5}\end{array}$ & $\begin{array}{l}\text { Morganella } \\
\boldsymbol{N = 1}\end{array}$ \\
\hline Ampicillin & $2(3.8)$ & 0 & $1(20)$ & 0 & 0 & 0 \\
\hline Cotrimoxazole & $15(28.8)$ & $3(25)$ & $2(40)$ & 0 & 0 & 0 \\
\hline Cefotaxime & $32(61.5)$ & $5(41.6)$ & $2(40)$ & $2(100)$ & $3(60)$ & 0 \\
\hline Ceftriaxone & $40(76.9)$ & $6(50)$ & $2(40)$ & $2(100)$ & $3(60)$ & $1(100)$ \\
\hline Amikacin & $45(86.5)$ & $8(66.7)$ & $3(60)$ & $1(50)$ & $4(80)$ & $1(100)$ \\
\hline Nitrofurantoin & $42(80.7)$ & $4(33.3)$ & $1(20)$ & $1(50)$ & $3(60)$ & 0 \\
\hline Ciprofloxacin & $40(76.9)$ & $3(25)$ & $2(40)$ & $1(50)$ & $3(60)$ & 0 \\
\hline Gentamycin & $39(75)$ & $3(25)$ & $3(60)$ & 0 & $1(20)$ & 0 \\
\hline Imipenem & $52(100)$ & $10(83.3)$ & $5(100)$ & $2(100)$ & $4(80)$ & $1(100)$ \\
\hline Norfloxacin & $42(80.7)$ & $7(58.3)$ & $3(60)$ & 0 & $3(60)$ & 1 \\
\hline $\begin{array}{l}\text { Piperacillin- } \\
\text { Tazobactum }\end{array}$ & $50(96.1)$ & $11(91.7)$ & $4(80)$ & $2(100)$ & $4(80)$ & $1(100)$ \\
\hline
\end{tabular}


Table.3 In vitro Antibiotic Sensitivity Pattern of Gram Positive Bacteria.

Percentage is Written in Paranthesis

\begin{tabular}{|c|c|c|c|}
\hline & 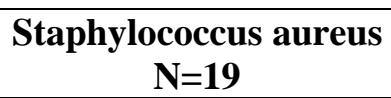 & $\begin{array}{l}\text { CONS } \\
\mathrm{N}=11\end{array}$ & $\begin{array}{c}\text { Enterococcus spp. } \\
\qquad=8\end{array}$ \\
\hline Ampicillin & $\begin{array}{c}3 \\
(15.7)\end{array}$ & $\begin{array}{c}2 \\
(18.1)\end{array}$ & 0 \\
\hline Cotrimoxazole & $\begin{array}{c}6 \\
(31.5)\end{array}$ & $\begin{array}{c}5 \\
(45.4)\end{array}$ & 0 \\
\hline Erythromycin & $\begin{array}{c}5 \\
(26.3) \\
\end{array}$ & $\begin{array}{c}3 \\
(27.2)\end{array}$ & 0 \\
\hline Amikacin & $\begin{array}{c}19 \\
(100)\end{array}$ & $\begin{array}{c}10 \\
(90.9)\end{array}$ & 0 \\
\hline Gentamycin & $\begin{array}{c}14 \\
(73.6) \\
\end{array}$ & $\begin{array}{c}9 \\
(81.9) \\
\end{array}$ & 0 \\
\hline Ciprofloxacin & $\begin{array}{c}10 \\
(52.7)\end{array}$ & $\begin{array}{c}10 \\
(90.9)\end{array}$ & $\begin{array}{c}1 \\
(12.5)\end{array}$ \\
\hline Vancomycin & $\begin{array}{c}19 \\
(100)\end{array}$ & $\begin{array}{c}11 \\
(100)\end{array}$ & $\begin{array}{c}8 \\
(100)\end{array}$ \\
\hline Oxacillin & $\begin{array}{c}9 \\
(47.3)\end{array}$ & $\begin{array}{c}9 \\
(81.9)\end{array}$ & - \\
\hline
\end{tabular}

Fig.1 Frequency of Uropathogens in Males

\section{Frequency of uropathogens in males}

E.

co

li 
Figure.2 Frequency of Uropathogens in Females

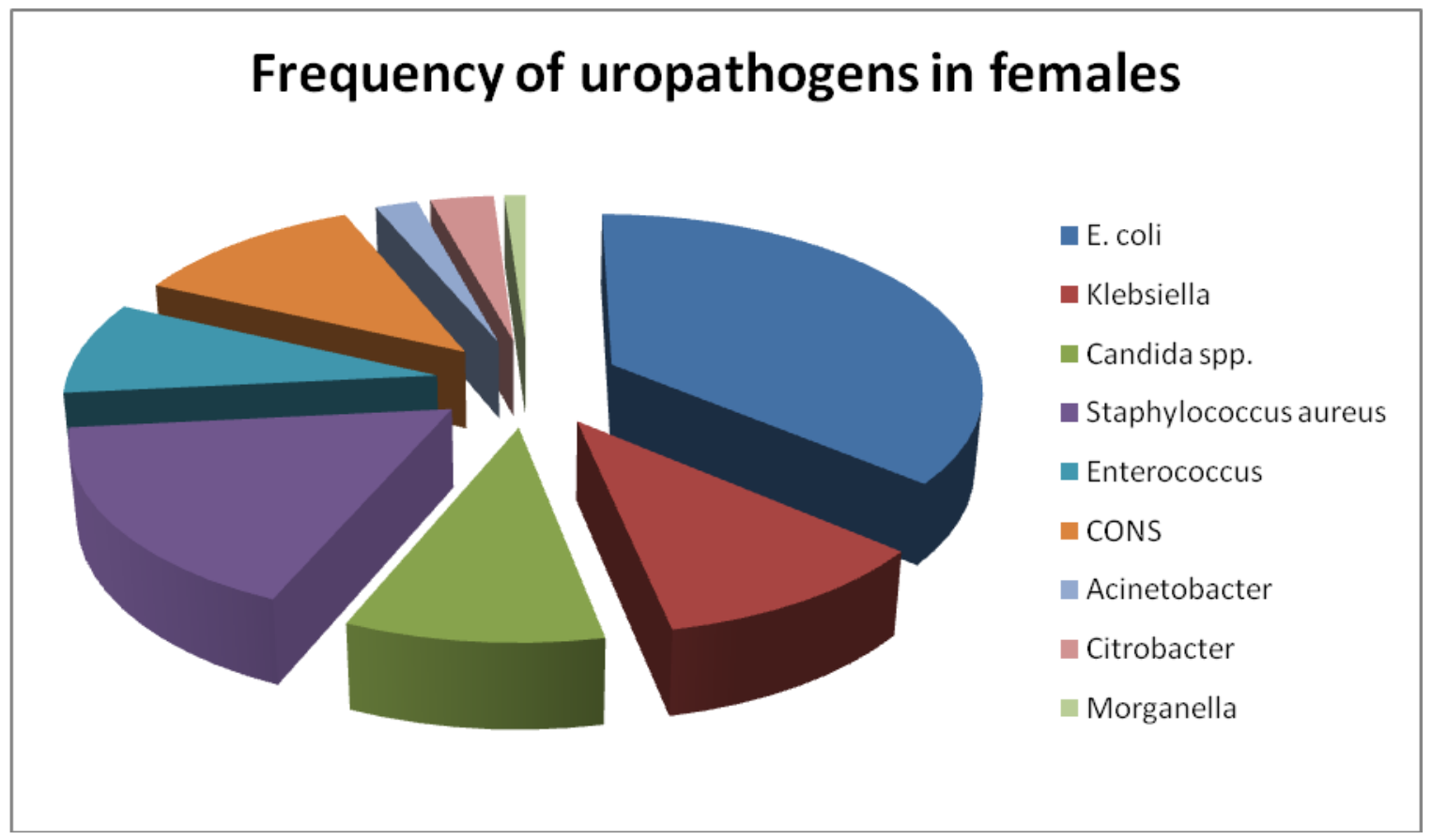

Prevalence of UTIs was more in females $(39.2 \%)$ when compared to males $(27.2 \%)$. This was in agreement with other studies (Bashir MF et al.,. 2008 and Getenet B. et al., 2011). Women are more prone to UTIs than men because, in females, the urethra is much shorter and closer to the anus.(Dielubanza EJ et al., 2011).

E.coli was the most common isolated organism in our study both in males and females $(60 \%$ in males \& $35 \%$ in females). This was similar to other studies .(Gupta KD et al,1999; Moges AF et al, 2002, Sibi et al 2011).

Other uropathogens isolated were Staphylococcus aureus, Coagulase negative Staphylococci, Klebsiella, Pseudomonas aeruginosa, Acinetobacter, Citrobacter, Morganella. Candida was isolated in 12 cases, 3 males \& 9 females.

In our study E-coli was most resistant to
Ampicillin (96.2\%). It was most sensitive to Imipenem (100\%) followed by Piperaciliintazobactum $(81.92 \%)$. The similar findings were seen in a study by Bashir MF et al who concluded that bacteria showed high resistance to older urinary antimicrobial agents such as ampicillin which may be due to its increased usage. ( Bashir MF et al., 2008) $76.9 \%$ of $E$. coli were sensitive to ciprofloxacin and $28.8 \%$ were sensitive to cotrimoxazole. Over the last decade, the treatment of choice for urinary tract infections (UTIs) has changed from cotrimoxazole to quinolones owing to the rate of resistance to Co-trimoxazole and its high level of therapeutic failure.( Yilmaz K et al., 2005).

Akram et al., reported ciprofloxacin resistance rates ranging from $47 \%$ to $69 \%$ among Gram negative organisms in their study in India (Akram M et al., 2007). $61.5 \%$ of $E$. coli were sensitive to cefotaxime \& $76.9 \%$ were sensitive to 
ceftriaxone. Sharifian et al., reported highest susceptibility percentage of E.coli to ceftriaxone $(97.8 \%)$ and cefotaxime $(95.2 \%)$ in 2006 in Tehran (M. Sharifian et al., 2006).

Only $15.7 \%$ of Staphylococcus aureus were sensitive to Ampicillin.All the Gram positive bacteria were $100 \%$ sensitive to vancomycin. The limitation of the study is that this being a retrospective study, the clinical history of the patients couldn't be traced.

In conclusion, higher prevalence of UTI was seen in females. Gram negative organisms were the most commonly isolated organisms in UTI among which $E$. coli was the most frequent causative agent both in males and females. Urinary pathogens showed resistance to commonly used antibiotics like Ampicillin, Cotrimoxazole. The susceptibility and resistance patterns of urinary pathogens should be considered before starting empirical treatment for UTI.

\section{References}

Al-Asmary SM, Al-Helali NS, Abdel-Fattah MM, Al-Jabban TM, Al-Bamri AM. Nosocomial urinary tract infection. Risk factors, rates and trends. Saudi Med J 2004;25:895-900.

Akram M, Shahid M, Khan AU. Etiology and antibiotic resistance pattern of community acquired urinary travt infections in JNMC Hospital Aligarh, India. Ann Clin Microbiol Antimicrob. 2007;6:4

Betty AF, Daniel FS, Alice SW. Overview of bacterial identification and strategies. In:Bailey and Scott's Diagnostic Microbiology. 12th ed. Philadelphia: Mosby; 2007. p. 21647.

Bauer AW, Kirby WMM, Sherris JC, Turch M. Antibiotic susceptibility testing by a standardized single disc method. Am J Clin Pathol. 1966; 45:493-9.

Bashir MF, Qazi JI, AhmadN Riaz S. Diversity of urinary tract pathogens and drug resistant isolates of Escherichia coli in different age and gender groups of Pakistanis. Tropical Journal of Pharmaceutical Research September 2008; 7 (3): 1025-1031

CLSI. Performance standards for antimicrobial disc susceptibility tests; Vol. 31 No. 1. CLSI 2011; document M100-S21.

Dielubanza EJ, Schaeffer AJ (2011 Jan). Urinary tract infections in women. The Medical clinics of North America 95 (1): 27-41.

Farrell DJ, Morrissey I, De Rubeis D et al. A UK multicentre study of the antimicrobial susceptibility of bacterial pathogens causing urinary tract infection. J Infect 2003; 46(2):94-100.

Rai, G.K., H.C. Upreti, S.K. Rai, K.P. Shah and R.M. Shrestha. Causative agents of urinary tract infections in children and their antibiotic sensitivity pattern: a hospital based study. Nepal Med Coll J 2008; 10(2): 86-90.

Getenet B, Wondewosen T. Bacterial Uropathogens in Urinary tract infections and Antibiotic susceptibility pattern in JIMMA University specialized hospital, Southwest Ethiopia. Ethiop J Health Sci. Vol. 21, No. 2 July 2011 (2):141-14621

Gupta KD, Scholes WE, Stamm. Increasing prevalence of antimicrobial resistance among uropathogens causing acute uncomplicated cystitis in women. Journal of the American Medical Association 1999; 281: 736738

Moges AF, Genetu A, Mengistu G. Antibiotic sensitivities of common 
bacterial pathogens in urinary tract infections at Gondar Hospital, Ethiopia. East Afr. Med. J. 2002; 79: 140-142.

Sharifian, M., A. Karimi, SR Tabatabaei and N. Anvaripour.Microbial sensitivity pattern in urinary tract infections in children: a single centre experience of 1177 urine cultures. Japanese Journal of Infectious Diseases, 2006; 59 (6): 380-382

Naveen R, Mathai E. Some virulence characteristics of uropathogenic Escherichia coli in different patient groups. Indian $\mathbf{J}$ Med Res 2005;122:143-7

Sobel JD, Kaye D. Urinary tract infections. In: Mandell GL, Bennett JE, Dolin $\mathrm{R}$, editors. Mandell, Douglas and Bennett's principles and practice of infectious diseases. 7th ed. vol. 1. Philadelphia, USA: Churchill Livingstone Elsevier publication; 2010. p. 958-72.
Sibi, G, Devi AP, Fouzia K, Patil BR. Prevalence, microbiologic profile of urinary tract infection and its treatment with trimethoprim in diabetic patients. Research Journal of Microbioogy 2011; 6: 543-551.

Tambekar DH, Dhanorkar DV, Gulhane SR, Khandelwal VK, Dudhane MN. Antibacterial susceptibility of some urinary tract pathogens to commonly used antibiotics. Afr J Biotechnol 2006;5:1562-5

Wilson ML, Gaido L. Laboratory Diagnosis of Urinary Tract Infections in Adult Patients. Clin Infect Dis 2004; 38:1150-8.

Yilmaz K, Nilay C, Aysegül G, et al. Cotrimoxazole and quinolone resistance in Escherichia coli isolated from urinary tract infections over the last 10 years. International $\mathbf{J}$ Antimicrbial Agents. 2005; 26 (1): 75-77.

\section{How to cite this article:}

Mamatha P Samaga and N.S. Sahana Shetty. 2016. Urinary Pathogens and their Antibiotic Susceptibility Pattern in MIMS, Mandya, India. Int.J.Curr.Microbiol.App.Sci.5(2): 323-329. doi: http://dx.doi.org/10.20546/ijcmas.2016.502.037 